\title{
MicroRNAs and Metabolism: Revisiting the Warburg Effect with Emphasis on Epigenetic Background and Clinical Applications
}

\author{
Zsuzsanna Gaál
}

Citation: Gaál, Z. MicroRNAs and Metabolism: Revisiting the Warburg Effect with Emphasis on Epigenetic Background and Clinical Applications. Biomolecules 2021, 11, 1531. https:// doi.org/10.3390/biom11101531

Academic Editors: Klaudia Skrzypek and Agnieszka Łoboda

Received: 21 September 2021

Accepted: 13 October 2021

Published: 17 October 2021

Publisher's Note: MDPI stays neutral with regard to jurisdictional claims in published maps and institutional affiliations.

Copyright: (C) 2021 by the author. Licensee MDPI, Basel, Switzerland. This article is an open access article distributed under the terms and conditions of the Creative Commons Attribution (CC BY) license (https:// creativecommons.org/licenses/by/ $4.0 /)$.
Department of Pediatric Hematology-Oncology, Institute of Pediatrics, University of Debrecen, 4032 Debrecen, Hungary; gaal.zsuzsanna@med.unideb.hu

\begin{abstract}
Since the well-known hallmarks of cancer were described by Hanahan and Weinberg, fundamental advances of molecular genomic technologies resulted in the discovery of novel puzzle pieces in the multistep pathogenesis of cancer. MicroRNAs are involved in the altered epigenetic pattern and metabolic phenotype of malignantly transformed cells. They contribute to the initiation, progression and metastasis-formation of cancers, also interacting with oncogenes, tumor-suppressor genes and epigenetic modifiers. Metabolic reprogramming of cancer cells results from the dysregulation of a complex network, in which microRNAs are located at central hubs. MicroRNAs regulate the expression of several metabolic enzymes, including tumor-specific isoforms. Therefore, they have a direct impact on the levels of metabolites, also influencing epigenetic pattern due to the metabolite cofactors of chromatin modifiers. Targets of microRNAs include numerous epigenetic enzymes, such as sirtuins, which are key regulators of cellular metabolic homeostasis. A better understanding of reversible epigenetic and metabolic alterations opened up new horizons in the personalized treatment of cancer. MicroRNA expression levels can be utilized in differential diagnosis, prognosis stratification and prediction of chemoresistance. The therapeutic modulation of microRNA levels is an area of particular interest that provides a promising tool for restoring altered metabolism of cancer cells.
\end{abstract}

Keywords: cancer epigenetics; microRNAs; metabolism; Warburg effect; personalized treatment

\section{Introduction}

Resulting from the advances in molecular biology, cell biology and genomics, the six well-known fundamental alterations of cancer, defined by Hanahan and Weinberg in 2000 (self-sufficiency in growth signals, insensitivity to growth inhibitory signals, evasion of programmed cell death, limitless replicative potential, sustained angiogenesis, tissue invasion and metastasis [1]), have been extended with novel hallmarks in 2011, which included genome instability, tumor-promoting inflammation, evading immune destruction and reprogramming energy metabolism [2]. However, Otto Warburg was awarded the Nobel Prize in 1931 for his discovery of cytochrome c oxidase, not for the formulation of the Warburg hypothesis [3], his observation that tumors take up and ferment high amounts of glucose to produce lactate even in the presence of oxygen $[4,5]$ forms the basis of our current knowledge on the metabolic reprogramming of cancer cells.

Besides characterization of the unique metabolic phenotype of malignantly transformed cells, the better understanding of their epigenetic alterations is another cornerstone of current cancer research, casting new light on targeted therapeutic interventions. Pioneering work carried out by Miescher, Flemming, Kossel and Heitz between 1869 and 1928 resulted in the cytological distinction between regions of euchromatin and heterochromatin $[6,7]$. The first definition of epigenetics originated from Conrad Hal Waddington, who established this term in 1942 to describe inherited changes in phenotype without changes in the sequence of the DNA [8,9]. Four decades later, the first human disease to be 
linked to epigenetics was cancer. In 1983, Feinberg and Vogelstein described substantial hypomethylation in genes of cancer cells compared with their normal counterparts [10,11].

The recent explosion of our knowledge on epigenetic regulation highlights its importance in the pathogenesis of human cancer [12]. Epigenetic and metabolic alterations in cancer are not independent, but highly intertwined with each other [13]. Epigenetic modifiers require a series of metabolite cofactors, while the expression of metabolic enzymes is regulated by epigenetic mechanisms in a significant manner [14].

Since the first microRNA was identified in 1993 (transcribed from the Caenorhabditis elegans lin-4 locus [15]), it has become clear that microRNAs are strongly involved in the maintenance of both homeostatic chromatin structure and metabolic homeostasis. In this Review, we discuss the role of microRNAs in cancer epigenetics and their involvement in the altered metabolic phenotype of malignantly transformed cells, putting special emphasis on clinical applications and precision treatment approaches.

\section{MicroRNAs and Carcinogenesis}

MicroRNAs are a class of phylogenetically conserved, non-coding RNAs, with approximately 22-25 nucleotides in length [16,17]. During the multistep biogenesis of microRNAs, the long primary transcript is first trimmed into a hairpin-structured intermediate that is exported from the cell nucleus by the Exportin-5 transporter, in a Ran-GTP dependent manner [18]. In the cytoplasm, a miRNA:miRNA* duplex is formed, one strand of which is later incorporated into the effector complex named RNA-induced silencing complex (RISC) [19]. During the maturation of microRNAs, two consecutive cleavage steps are mediated by the RNase III endonuclease enzymes Drosha and Dicer [20]. MicroRNAs generally act as posttranscriptional repressors. They bind to the $3^{\prime}$ untranslated region (UTR) of the target mRNA [21], which is recognized by the microRNA seed sequence, located between the second and eighth nucleotides at their $5^{\prime}$ end [14]. Redundancy of the regulation is featured by the numerous targets of each microRNA, while a single mRNA can also be targeted by several different microRNAs [22].

The significant role of microRNAs during carcinogenesis is supported by increasing amounts of evidence [19]. The expression pattern of microRNAs distinguishes tumors of different developmental origin $[23,24]$, therefore, their expression profiles can be utilized for the classification of human malignancies [25]. Alteration of microRNA expression levels in cancer was first reported in 2002 by Calin et al., when miR-15 and miR-16 were identified at 13q14.3, a frequently deleted region in chronic lymphocytic leukemia (CLL) [26]. During the next decade, it became clear that microRNAs are involved in the pathogenesis of all types of hematological malignancies and solid tumors [27]. This is in accordance with the finding that more than $50 \%$ of microRNA genes are located in cancer-associated genomic regions (CAGR) [28], and their targets include key regulators of cell cycle, proliferation, cell adhesion, apoptosis, angiogenesis and DNA repair [29,30].

MicroRNAs are involved in tumor initiation, progression and metastasis formation [31]. They are responsible for the regulation of interactions between cancer cells and cells of the tumor microenvironment including immune cells [15]. Furthermore, they can act either as tumor suppressors (anti-oncomiRs) or as oncogenic microRNAs (oncomiRs) by targeting oncogenes and tumor suppressor mRNAs, respectively [28]. However, certain microRNAs (e.g., miR-29) act as a tumor suppressor in leukemia and function as an oncomiR in solid tumors [31].

Impaired microRNA regulation of cell cycle progression contributes to the transformation of stem cells [32]. MicroRNAs regulate cyclin-dependent protein kinases (CDKs) and cyclines, moreover, the expression levels of numerous microRNAs vary between normal stem cells and cancer stem cells (CSCs) [32]. The miR-17-92 cluster cooperates with the c-Myc oncogene to prevent apoptosis in CSCs by targeting E2F and cyclin D [33], while the let-7 family of microRNAs has been shown to suppress epithelial-mesenchymal transition and other CSC characteristics by the regulation of numerous cell cycle components, such 
as CDK4, CDK6 and CDC25A [34]. MiR-377 and miR-145 are involved in the regulation of CSC properties in colon cancer and prostate cancer, respectively [35,36].

Disturbances of the microRNA biogenesis pathway have also been reported in numerous cancer types. Mutations in genes that encode Drosha, Dicer and Exportin-5, or mutations within the binding sites of target mRNAs, can contribute to the development of malignant diseases [15].

However, the expression of microRNAs is tightly controlled by transcription factors, microRNAs are also susceptible to epigenetic modulation [37]. Epigenetic inactivation by promoter hypermethylation has been detected in case of the tumor suppressor microRNAs miR-124 and miR-34a in hematological malignancies [38,39]. MicroRNAs regulate several enzymes of DNA methylation and histone modification, among which strong interconnections have been confirmed [40]. A typical example for the complexity of interactions is the regulatory loop between the anti-oncomiR miR-34a and the histone deacetylase enzyme SIRT1. MiR-34a mediates the repression of SIRT1, resulting in the inhibition of sterol-regulatory element-binding proteins (SREBPs) and nuclear factor $\mathrm{KB}(\mathrm{NF} \kappa \mathrm{B})$, while SIRT1 inhibits miR-34a by deacetylating its promoter [41]. The complex role of microRNAs during carcinogenesis is illustrated in Figure 1.

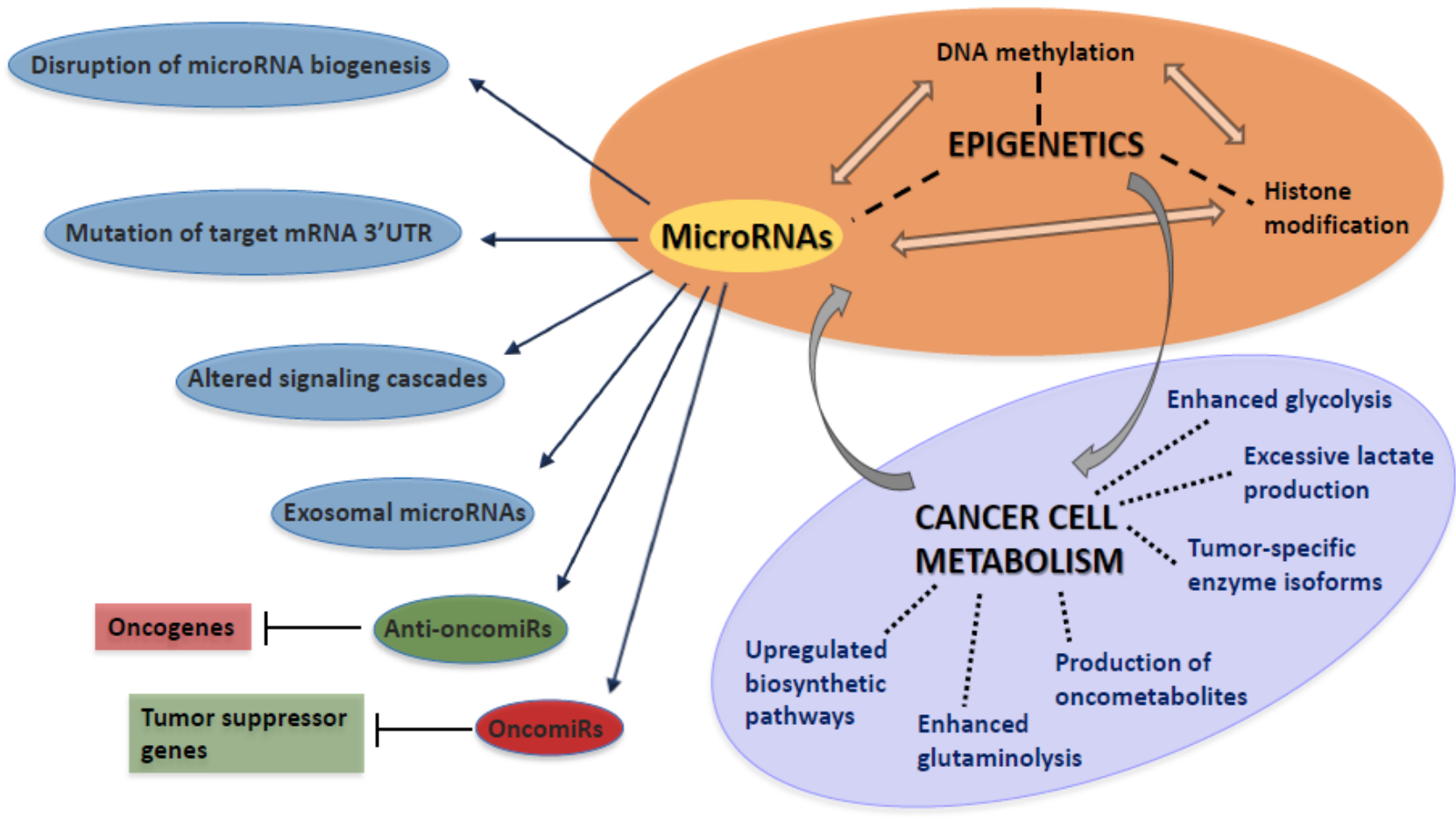

Figure 1. MicroRNAs contribute to the initiation and progression of cancer by a wide variety of different mechanisms, including multiple interactions with oncogenes, tumor suppressor genes, DNA methylation and histone modification. Altered microRNA expression levels are also involved in the metabolic reprogramming of cancer cells. Targeting such Warburg-related microRNAs is a promising therapeutic approach. UTR: untranslated region.

\section{Implication of MicroRNAs in the Regulation of Metabolic Pathways}

The first microRNA to be linked to metabolic regulation was miR-122 [42], which is expressed primarily in the liver, regulating lipid metabolism and liver cell differentiation [41]. Since then, growing number of microRNAs have been confirmed to regulate metabolic pathways [41]. MiR-33, contained by the primary transcript of SREBP2 (as an intronic microRNA), is involved in the regulation of cellular cholesterol export and fatty acid $\beta$-oxidation [43]. Furthermore, the $\alpha 1$ subunit of the nutrient and energy sensor AMP-dependent protein kinase (AMPK) is also targeted by this microRNA [41]. 
However, the best-characterized microRNAs in metabolic control are responsible for the maintenance of cholesterol and lipid homeostasis, and new data revealed the involvement of numerous microRNAs in the regulation of glucose homeostasis and insulin signaling as well [41]. MiR-103 and miR-107 regulate insulin and glucose homeostasis, while miR-223 controls the uptake of glucose in skeletal muscle by targeting glucose transporter 4 (GLUT4) [41]. MiR-375 was confirmed to be one of the key regulators of insulin secretion [41]. $\mathrm{X}$ component and B subunit of pyruvate dehydrogenase enzyme (PDH) are targeted by miR-26a [44] and miR-146b [45], respectively. Mitochondria has a central bioenergetic role due to encompassing important pathways of the carbohydrate, lipid and amino acid metabolism that are also under the control of microRNAs. The electron transport chain (ETC), tricarboxylic acid (TCA) cycle, fatty acid $\beta$-oxidation and amino acid metabolism are regulated by a large number of microRNAs, such as miR-210, miR-181a, miR-370 and miR-23a, respectively [46].

According to recently published data, the expression levels of metabolism-regulating microRNAs are modulated by a wide variety of environmental factors, including physical activity and nutrition. On a mouse model, altered microRNA expression profiles were detected in case of caloric restriction and high-fat diet [47]. Involvement of microRNAs in exercise adaptation has also been confirmed [48]. Maintenance of health requires the appropriate control of metabolic homeostasis [41]. A growing amount of evidence highlights the dysregulation of microRNAs in insulin resistance, diabetes, non-alcoholic fatty liver disease (NAFLD) and other metabolic disorders, in which specific microRNA signatures have been identified $[41,49,50]$. Based on the reversible and targetable changes of microRNA expression levels, their role in the metabolic reprogramming of cancer cells is an area of particular interest.

\section{The Warburg Effect}

In the late 1920s, Otto Warburg hypothesized that the glycolytic switch of cells causes cancer: "The origin of cancer lies in the anaerobic metabolic component of normal growing cells, which is more resistant to damage than is the respiratory component. Damage to the organism favours this anaerobic component and, therefore, engenders cancer" [51,52]. However, Warburg later proposed that mitochondrial dysfunctional is the root of aerobic glycolysis [53,54], and mitochondrial dysfunction promotes the Warburg effect only in a minority of tumors [55]. Metabolic alterations in proliferating cancer cells are induced by interactions between oncogenes and tumor suppressor genes that are also under the control of signaling cascades and microRNAs [56-58]. Therefore, glycolytic switch is considered to be an early event in oncogenesis [55] that is an outcome of oncogenic mutations [59].

The most well-known hallmark of the metabolic reprogramming of cancer cells is that the rate of glycolysis and lactate production is greatly increased, even in the presence of oxygen (aerobic glycolysis) [60,61]. The expression of the vast majority of glycolytic genes is regulated by c-Myc and hypoxia inducible factor $1 \alpha$ (HIF1 $\alpha)$ transcription factors [62]. According to recently published data, aerobic glycolysis in Burkitt lymphoma cells is regulated by c-Myc, whereas in lymphoblastoid cell lines, HIF1 $\alpha$ is responsible for the same phenomenon [63]. The hypoxia responsive elements (HRE) also encode for CXCR4 and CXCL12, which play an important role in the homing and preservation of leukemia stem cells [64]. High glycolytic rate is supported by some tumor-specific enzyme isoforms, such as hexokinase 2 (HK2) and pyruvate kinase M2 (PKM2) [65]. Besides the backup of glycolytic phospho-intermediates to be shuttled into biosynthetic pathways [55], nonmetabolic functions of PKM2 have also been revealed that are essential for cell cycle progression and carcinogenesis [66]. Enhanced glycolysis is counterbalanced by the tumor suppressor p53 protein, that regulates the expression of TP53-induced glycolysis and apoptosis regulator (TIGAR), an enzyme responsible for decreasing the level of fructose2,6-bisphosphate in cells [67].

Similarly to glycolytic enzymes, GLUT1, a rate-limiting factor for glucose uptake, is also aberrantly expressed in several tumor types [68]. Excessive glycolysis results in 
the excessive formation of lactate, which contributes to resistance against conventional therapies [55]. Tumor-derived lactate promotes the M2 polarization of tumor-associated macrophages, thereby suppressing anticancer immune response [61]. Lactate is excreted from cells by the lactate-proton symporter enzyme monocarboxylate transporter 4 (MCT4), expression of which is also under the control of HIF1 $\alpha$ [69].

Sustained bioenergetic demand, required by uncontrolled proliferation, addicts cancer cells to an adequate anabolic supply [3]. The increased glucose consumption is used as a carbon source for de novo generation of nucleotides, proteins and lipids that can be diverted into multiple branching pathways, such as de novo biosynthesis of serine [61]. Substantially increased glutaminolysis serves as a major nitrogen source for proliferating cells, which also provides citrate to be utilized in fatty acid and cholesterol synthesis [70]. Upregulated activity of the pentose phosphate pathway (PPP) is essential for the high rate of nucleic acid synthesis, while the generation of NADPH provides a scavenger of reactive oxygen species (ROS) [71]. The production of ROS is elevated in malignantly transformed cells, resulting from increased metabolic rate and modifications in signaling pathways that affect cellular metabolism [66,72]. To counterbalance the higher production of ROS, the rate of ROS scavenging is also elevated in many tumors $[66,73]$. In contrast, the mutation of isocitrate dehydrogenase 1 (IDH1) enzyme results in the accumulation of lipid ROS, due to the reduced level of glutathione peroxidase 4 (GPX4) protein [74].

Besides losing their normal catalytic activity, mutant IDH1 and IDH2 gain the function of catalyzing the reduction of alpha-ketoglutarate $(\alpha-K G)$ to the oncometabolite 2hydroxyglutarate (2-HG), that is a competitive inhibitor of numerous $\alpha$-KG-dependent enzymes [75]. $\alpha$-KG-dependent hydroxylases are a class of non-heme iron proteins, including TET enzymes of DNA hydroxymethylation, Jumonji-domain- (JMJD) containing histone demethylases and prolyl hydoxylase (PHD) enzymes that hydroxylate proline residues within the oxygen-dependent domains, resulting in the proteasomal degradation of the HIF1 $\alpha$ transcription factor [76]. The PHD enzymes also have HIF1 $\alpha$-independent functions and among other factors, are also subject to regulation by the abnormal levels of oncometabolites that have been observed in many types of cancer [62]. According to recently published results, 2-HG accumulates in the extracellular space and is taken up by $\mathrm{T}$ lymphocytes, thereby compromising anticancer immune responses [77]. In case of cytogenetically normal acute myeloid leukemia (AML), high level of 2-HG was identified as a strong negative prognostic factor, independent of other molecular features [78]. Besides $\mathrm{IDH}$, mutations of other TCA cycle enzymes, such as succinate dehydrogenase (SDH) and fumarate hydratase (FH), also lead to metabolic shifts of the cell due to the activation of HIF1 $\alpha$-mediated glucose utilization $[57,79]$.

In summary, metabolic features of cancer cells can be distinguished as convergent and divergent metabolic phenotypes [80]. Enhanced glycolysis is the best example to convergent properties, which are shared among diverse types of tumors, while the stimulation of heterogeneous pathways results in divergent properties, such as the accumulation of 2-HG in case of IDH1 and IDH2 mutations [80]. Special metabolic symbiosis between cancer cells and cancer-associated stroma has also been described (referred to as the reverse Warburg effect), when glycolysis in the stromal cells supports adjacent cancer cells by the transfer of catabolites including lactate, pyruvate and ketone bodies [81].

\section{MicroRNAs as Key Regulators of Cancer Metabolism-Epigenetic Background of the Warburg Effect}

The strong intertwining between signaling molecules, oncogenes and tumor suppressor genes that are involved in the metabolic reprogramming of cancer cells [82] becomes an even more complex network by the regulation of these genes by microRNAs. The expression of c-Myc transcription factor is inhibited by p53-induced microRNAs miR-145 and miR-34c, while c-Myc was confirmed to activate the transcription of the oncogenic miR-17-92 cluster [58]. Based on its strong impact on glycolysis, TCA cycle and oxidative phosphorylation, the miR-17-92 cluster is considered to play a central role in the c-Myc driven metabolic reprogramming of cancer cells [83] (Table 1). 
Table 1. MicroRNAs are involved in both the maintenance of metabolic homeostasis and the metabolic reprogramming of cancer cells. Examples for Warburg-promoting and anti-Warburg microRNAs are highlighted with blue and green background, respectively.

\begin{tabular}{|c|c|}
\hline MicroRNA & Implication in Metabolic Regulation and Targets \\
\hline miR-1 & G6PD \\
\hline miR-15 & BCL2, FASN \\
\hline miR-16 & BCL2, FASN \\
\hline miR-17-92 cluster & glycolysis, TCA, oxidative phosphorylation, E2F, cyclin D \\
\hline miR-22 & ACLY \\
\hline miR-23a & amino acid metabolism, GLS \\
\hline miR-23b & amino acid metabolism, GLS \\
\hline $\mathrm{miR}-26 \mathrm{a}$ & pyruvate-lactate conversion, $\mathrm{PDH} X$ component \\
\hline miR-33 & fatty acid $\beta$-oxidation \\
\hline miR-34a & LDH-A, SIRT1 \\
\hline miR-122 & lipid metabolism, PKM2 \\
\hline miR-103 & insulin and glucose homeostasis \\
\hline miR-107 & insulin and glucose homeostasis \\
\hline miR-132 & GLUT1 \\
\hline miR-137 & ASCT2 \\
\hline miR-144 & GLUT1 \\
\hline miR-146b & pyruvate-lactate conversion \\
\hline miR-181a & TCA \\
\hline miR-155 & HK2 \\
\hline miR-199a & HK2 \\
\hline miR-206 & G6PD \\
\hline $\operatorname{miR}-210$ & electron transport chain, glycolytic enzymes, ISCU \\
\hline $\operatorname{miR}-223$ & GLUT4 \\
\hline miR-326 & PKM2 \\
\hline $\operatorname{miR}-370$ & fatty acid $\beta$-oxidation \\
\hline miR-375 & insulin secretion \\
\hline $\operatorname{miR}-422$ & PDK2 \\
\hline $\operatorname{miR}-451$ & GLUT1 \\
\hline miR-497 & transketolase \\
\hline
\end{tabular}

Abbreviations: ACLY: ATP citrate lyase; ASCT2: alanine/serine/cysteine-preferring transporter 2; BCL2: Bcell lymphoma 2 gene; CDK: cyclin-dependent protein kinase; FASN: fatty acid synthase; G6PD: glucose-6phosphate dehydrogenase; GLS: glutaminase; GLUT: glucose transporter; HK2: hexokinase 2 isoform; ISCU: ironsulfur cluster assembly enzyme; LDH: lactate dehydrogenase; PDH: pyruvate dehydrogenase; PDK2: pyruvate dehydrogenase kinase 2; PKM2: pyruvate kinase M2 isoform; SIRT: sirtuin enzyme; TCA: tricarboxylic acid cycle.

MiR-210, induced by the HIF1 $\alpha$, targets the mitochondrial iron-sulfur cluster assembly enzyme (ISCU) that provides cofactors for enzymes involved in the Krebs cycle and electron transport, therefore, the suppression of ISCU results in a shift to glycolysis under normoxic conditions $[58,84]$.

A set of microRNAs (including miR-132, miR-144, miR-148b, miR-340 and miR-451) suppresses GLUT1-mediated glucose uptake, among which miR-132 was found to be downregulated in numerous types of cancer [85,86]. The tumor-specific HK2 isoform is regulated by both oncogenic and tumor suppressor microRNAs, such as miR-155 and miR-199a, respectively [82,87]. Another tumor-specific enzyme isoform, PKM2, is inhibited by miR-326 and miR-122, the latter of which is considered to be a tumor suppressor 
microRNA that decreases the occurrence of metastasis in hepatocellular carcinoma via the downregulation of PKM2 [88,89].

Lactate dehydrogenase (LDH) is a tetrameric enzyme, the subunits of which are encoded by two different genes, LDH-A and LDH-B. Elevated LDH-A/LDH-B ratio is characteristic to tumor cells and promotes lactate formation in a significant manner. While HIF1 $\alpha$ - and c-Myc-related pathways promote the expression of LDH-A [90], overexpression of the tumor suppressor miR-34a counteracts this effect [91]. Similarly to miR-34a, miR-422 also inhibits the Warburg effect. Activity of pyruvate dehydrogenase (PDH) can be restored via the suppression of pyruvate dehydrogenase kinase 2 (PDK2) by miR-422, that was found to be downregulated in gastric cancer [92]. On the other hand, miR-26a promotes the Warburg effect by targeting the $\mathrm{X}$ component of $\mathrm{PDH}$, and thereby inhibiting the key step of glycolysis entry into the TCA cycle [44].

Glutamine metabolism and enzymes of the PPP are also regulated by microRNAs. The alanine/serine/cysteine-preferring transporter 2 (ASCT2) of glutamine, upregulated in different kinds of cancer, is targeted by miR-137 [93], while the repression of miR-23a and miR-23b resulted in a higher expression level of glutaminase enzyme (GLS) [94]. ATP citrate lyase (ACLY), which is a key enzyme of de novo fatty acid synthesis, was found to be upregulated in numerous types of cancer, and it is inhibited by miR-22 in osteosarcoma and lung cancer cells [95]. Fatty acid synthase (FASN) is a central lipogenic enzyme that is targeted by miR-15 and miR-16. FASN was found to be upregulated in breast cancer [96]. MiR-1, miR-122 and miR-206 negatively regulate the expression of glucose-6-phosphate dehydrogenase (G6PD), the enzyme that catalyzes the first reaction of PPP [71]. Transketolase, involved in the non-oxidative phase of PPP, is targeted by miR-497, a microRNA that modulates cisplatin chemosensitivity of cervical cancer cells $[97,98]$.

Besides microRNAs, DNA-methylation and a wide variety of histone modifications also contribute to the metabolic reprogramming of cancer cells, thereby composing a complex epigenetic background of the Warburg effect. Promoter methylation of the glycolysis antagonist fructose-1,6-bisphosphatase-1 (FBP1) is promoted by the NFkB pathway, and can be used as a biomarker for prognosis prediction in gastric cancer [99]. The promoter hypermethylation of LDH-B, detected in breast and prostate cancer, can be restored by the demethylating agent 5-azacytidine [100]. Methylation of PKM2 by coactivator-associated arginine methyltransferase 1 (CARM1) at three arginine residues results in the localization of PKM2 to the mitochondria-associated endoplasmic reticulum membrane, which promotes aerobic glycolysis by decreasing $\mathrm{Ca}^{2+}$-uptake and mitochondrial membrane potential [101]. Promoter hypermethylation of Derlin-3, which is implicated in GLUT1 proteasome degradation, contributes to the overexpression of GLUT1 transporter [102].

Monoubiquitination of histone H2B (H2Bub1) exerts an anti-Warburg effect by regulating the expression of mitochondrial respiratory genes. In addition, PKM2 interacts with $\mathrm{H} 2 \mathrm{~B}$ and decreases the level of H2Bub1 [103]. Members of the NAD ${ }^{+}$-dependent sirtuin family of histone deacetylase enzymes play an important role in the metabolic regulation of cancer cells [104,105]. In tumor cell lines, the absence of SIRT3 led to the overproduction of ROS, resulting in the stabilization of HIF1 $\alpha$ and the upregulation of its glycolytic targets [106]. SIRT4 enzyme has been identified as a tumor suppressor and glutamine gatekeeper, which inhibits the glutamate dehydrogenase (GDH) enzyme [107]. In mouse embryonic fibroblasts, loss of SIRT4 enzyme resulted in increased glutamine-dependent proliferation and stress-induced genomic instability [108,109]. Recently published data also suggest the antitumor activity of the HIF1 $\alpha$ corepressor SIRT6 enzyme. Besides its impact on the expression of glycolytic genes, SIRT6 also regulates the splicing of the tumor-specific PKM2 isoform [110].

All in all, besides the protein-coding oncogenes and tumor suppressor genes, epigenetic regulatory mechanisms such as DNA methylation, sirtuin enzymes and microRNAs are also key regulators of the Warburg effect, providing an unprecedented scale of potential therapeutic targets. 


\section{Clinical Applications}

Advances in molecular biology and genomics opened up new horizons for anticancer treatment, targeting metabolic pathways, microRNAs and epigenetic regulators. Chemoand radiotherapy-resistant breast cancer cells were re-sensitized by 2-deoxyglucose, a competitive inhibitor of glucose [111]. WZB117, an inhibitor of GLUT1 [112], was confirmed to exert synergistic effects with paclitaxel and cisplatin [65]. Pharmacological inhibition of GLUT1 with BAY-876 impaired the growth of triple-negative breast cancer cells [113], while the inhibition of GLUT3-transporter resulted in delayed resistance to temozolomide in the treatment of glioblastoma [114].

Co-administration of glucocorticoids with inhibitors of HK2, such as 3-bromopyruvate, increased in vitro sensitivity of glucocorticoids in acute lymphoblastic leukemia (ALL) [115]. In human lung cancer cells, the silencing of PKM2 resulted in the increased efficacy of docetaxel in vitro and in vivo [116]. CPI-613 (devimistat) is a lipoate analog which inhibits PDH and $\alpha-K G$ dehydrogenase complexes [66]. CPI-613 re-sensitized AML cells to cytotoxic agents through the inhibition of TCA cycle [66]. While no specific inhibitors of wild-type IDH enzyme have been reported, potent inhibitors have been identified for mutant IDH1 and mutant IDH2. AGI-5198 was reported to inhibit the accumulation of 2-HG in IDH1-mutated glioma cells in vivo [117], that also promoted the differentiation of glioma cells [118]. In preclinical studies, epigallocatechin gallate was confirmed to interrupt the anaplerotic use of glutamine in the TCA cycle, thereby reducing tumor growth [119].

BPTES (bis-2-(5-phenylacetamido-1,2,4-thiadiazol-2-yl)-ethyl-sulfide) is an allosteric inhibitor of GLS1 enzyme. In pancreatic carcinoma, the synergistic effect of BPTES and doxorubicin was observed [59]. While ALL cells have an increased dependence on exogenous asparagine due to the decreased activity of asparagine synthetase enzyme [120], AML cell lines that are resistant to cytarabine therapy show a significant alteration to purine metabolism [121]. Etomoxir (irreversible inhibitor of carnitine palmitoyltransferase1) inhibited cell viability in glioblastoma cells with a significant reduction in ATP and NADPH levels [122]. Sensitivity against different kinds of antimetabolites also showed associations with cytogenetic properties. Comparing AML cell lines, NB4 (acute promyelocytic leukemia with $\mathrm{t}(15 ; 17)$ translocation) and THP-1 (acute monocytic leukemia with $\mathrm{t}(9 ; 11)$ translocation) cells exhibited increased sensitivity to 2-deoxyglucose and etomoxir, respectively [123].

Modulating the expression levels of microRNAs is receiving a great deal of attention in cancer. Two major fields are replenishing the expression of anti-oncomiRs, and targeting oncomiRs with microRNA antagonists (antimiRs) [124]. MicroRNA mimics are doublestranded molecules matching the corresponding microRNA sequence, while antimiRs have a single-stranded structure, classified as first-generation antisense oligonucleotides (ASOs) and locked nucleic acids (LNAs) [15]. There are several ongoing clinical trials such as the LNA-modified antimiR-155 in cutaneous T cell lymphoma and the miR-34 mimic lipid nanoparticles in multiple solid tumors [15]. Besides the growing number of therapeutic targets, the spectrum of delivery systems for microRNA therapeutics has also broadened and includes neutral lipid emulsions, dendrimers (polyamidoamine- or polypropylene imine-conjugated nucleic acids), cyclodextrin (glucose polymer), adenoviral vectors, polylactide-co-glycolide (PLGA) polymers, chitosan (cationic polymer derived from chitin) and bacterium-derived EnGeneIC Delivery Vehicle (EDV) nanocells (also called targomiRs) [15]. Targeting a wide variety of microRNAs (such as miR-122, miR-125b, miR-34a, miR-155 and miR-205) with these novel technologies can potentially normalize dysregulated metabolic enzymes in chemoresistant cancer cells [125]. Numerous microRNAs have been confirmed to enhance the efficacy of anticancer drugs [124]. Overexpression of the GLUT1-targeting miR-218 increased chemosensitivity of bladder cancer cells to cisplatin [86], while miR-153 enhanced sensitivity against arsenious acid in chronic myeloid leukemia (CML) [126]. Dietary microRNAs represent a new area and are released into the circulation after cellular uptake in the gastrointestinal tract. They are transported to 
multiple cell types and tissues, such as liver and immune cells, to directly regulate gene expression [127].

There are further promising clinical applications of microRNAs, including differential diagnosis, prediction of prognosis and chemoresistance. Based on the expression level of four microRNAs (miR-128a, miR-128b, let-7b and miR-223), ALL and AML can be distinguished with high accuracy (97-99\%) [128]. MicroRNA expression levels can be utilized in the early detection of bladder cancer [129] and in the differential diagnosis of non-small cell lung carcinoma [130]. Let-7a and miR-188 are prognostic biomarkers in cytogenetically normal AML [131]. A six-microRNA-based model has been described to improve prognosis prediction in breast cancer [132], and a five-microRNA-based signature was identified to have a significant prognostic value in colon cancer [133]. Downregulation of miR-181a was associated with cytarabine resistance in HL60 cells, due to reduced targeting of the BCL2 oncogene [134]. In glioma cell lines, miR-16 was confirmed to modulate temozolomide resistance by regulating BCL2 [135]. MicroRNAs have also been identified in exosomes, which can be taken up by neighboring or distant cells [136]. Exosomal microRNAs are involved in cancer progression and metastasis formation [136], they are ligands of toll-like receptors and activate immune cells [137]. A special circular RNA, hsa_circ_0005963 (ciRS122), is a sponge for the PKM2-targeting miR-122. Exosomes from oxaliplatin-resistant colorectal cancer cells delivered ciRS-122 to sensitive cells, thereby promoting glycolysis and chemoresistance [138]. Clinical applications of microRNAs and therapeutic approaches to counteract Warburg effect are summarized in Figure 2.

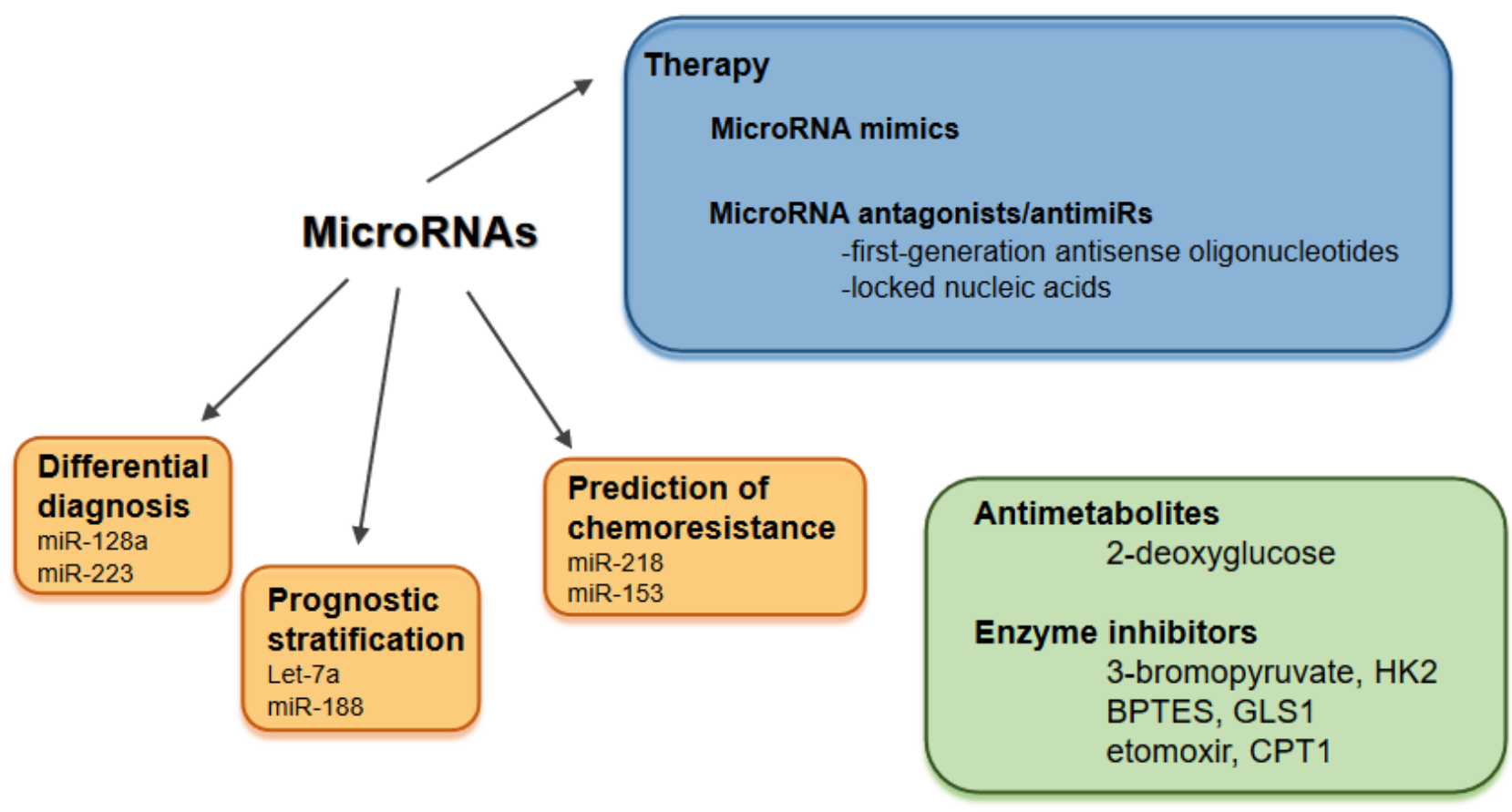

Figure 2. Clinical applications of microRNAs and therapeutic approaches to counteract Warburg effect. Abbreviations: BPTES: bis-2-(5-phenylacetamido-1,2,4-thiadiazol-2-yl)-ethyl-sulfide, CPT1: carnitine palmitoyltransferase-1, GLS: glutaminase enzyme, HK2: hexokinase 2 isoform.

\section{Concluding Remarks and Future Perspectives}

Epigenetic and metabolic alterations have been characterized as novel hallmarks of cancer during the past two decades. Better understanding of these features became a top priority of cancer research, which also revealed their multiple interactions with previously already well-characterized etiologic factors such as disturbances of signaling cascades, mutations in oncogenes and tumor suppressor genes. Mutations of epigenetic modifiers have been identified as early events in several cancers. The epimutation concept proposes the vertical transmission of an error-prone epigenetic pattern, resulting in the generation 
of clones with abnormal mitoses and malignant characteristics [139]. Altered epigenetic profile and metabolic reprogramming of cancer cells provide promising novel therapeutic targets. However, special challenges of such novel therapeutic approaches should be noted.

Treatments targeting altered metabolic phenotypes should consider the heterogeneity of metabolism between different types of tumors and even within distinct regions of a solid tumor [80]. Divergent metabolic properties (such as the accumulation of 2-HG) can be targeted with a more acceptable toxicity profile compared to that of convergent metabolic phenotypes [80]. Targeting CSC metabolism is also a promising treatment option in cancer. An increasing amount of evidence suggests the metabolic plasticity of CSCs, which contributes to their resistance to conventional therapies [140]. CSCs can favor glycolysis or oxidative phosphorylation, depending on the niche where they are located [141]. Based on the rapid transition of the metabolic phenotype of CSCs under glucose deprivation or hypoxia, targeting the adaptive mechanisms is an optional treatment approach [141].

Ensuring appropriate specificity is a topmost challenge of epigenetic therapies. Epigenetic drugs should be transmitted specifically to distinct regions of chromatin. Growing number of delivery vehicles and a wide variety of modified oligonucleotides have recently been constructed that can be utilized in the modulation of microRNA expression levels. MicroRNAs affect hundreds of targets in complex regulatory networks. Therefore, the context-dependent role of microRNAs should always be taken into consideration. Besides the therapeutic modulation of microRNA expression levels, a wide variety of their further clinical applications should be highlighted, including differential diagnosis, biomarkers for advanced prognostic stratification and prediction of chemoresistance. While the modulation of microRNA levels can enhance chemosensitivity, the impact of conventional chemotherapeutic agents on microRNAs also should be noted. For example, 5-fluorouracil has been shown to enhance the expression of anti-oncomiRs such as the let-7 family and miR-15b [134]. In recent years, the number of clinical trials targeting Warburg-related microRNAs has increased. Though the majority of these drugs were well tolerated, the possibility of unpredictable side effects is highlighted by the fact that the trial of MRX34 (miR-34 mimic molecule targeting LDH-A) was terminated due to severe immune-related reactions [142].

Early identification of reversible epigenetic and metabolic alterations is of key significance to increase the efficacy and reduce the toxicity of cancer treatment by advanced prognosis stratification and novel combinations of conventional and targeted therapeutic agents.

Funding: This research was funded by Foundation for Children with Leukemia and University of Debrecen University and National Library.

Institutional Review Board Statement: Not applicable.

Informed Consent Statement: Not applicable.

Data Availability Statement: No new data were created or analyzed in this study. Data sharing is not applicable to this article.

Conflicts of Interest: The author declares no conflict of interest.

\author{
Abbreviations \\ $\alpha-K G \quad$ alpha-ketoglutarate \\ ACLY ATP citrate lyase \\ ALL acute lymphoblastic leukemia \\ AML acute myeloid leukemia \\ AMPK adenosine monophosphate-dependent protein kinase \\ ASCT alanine/serine/cysteine-preferring transporter \\ ASO antisense oligonucleotide \\ BCL2 B-cell lymphoma 2 gene
}




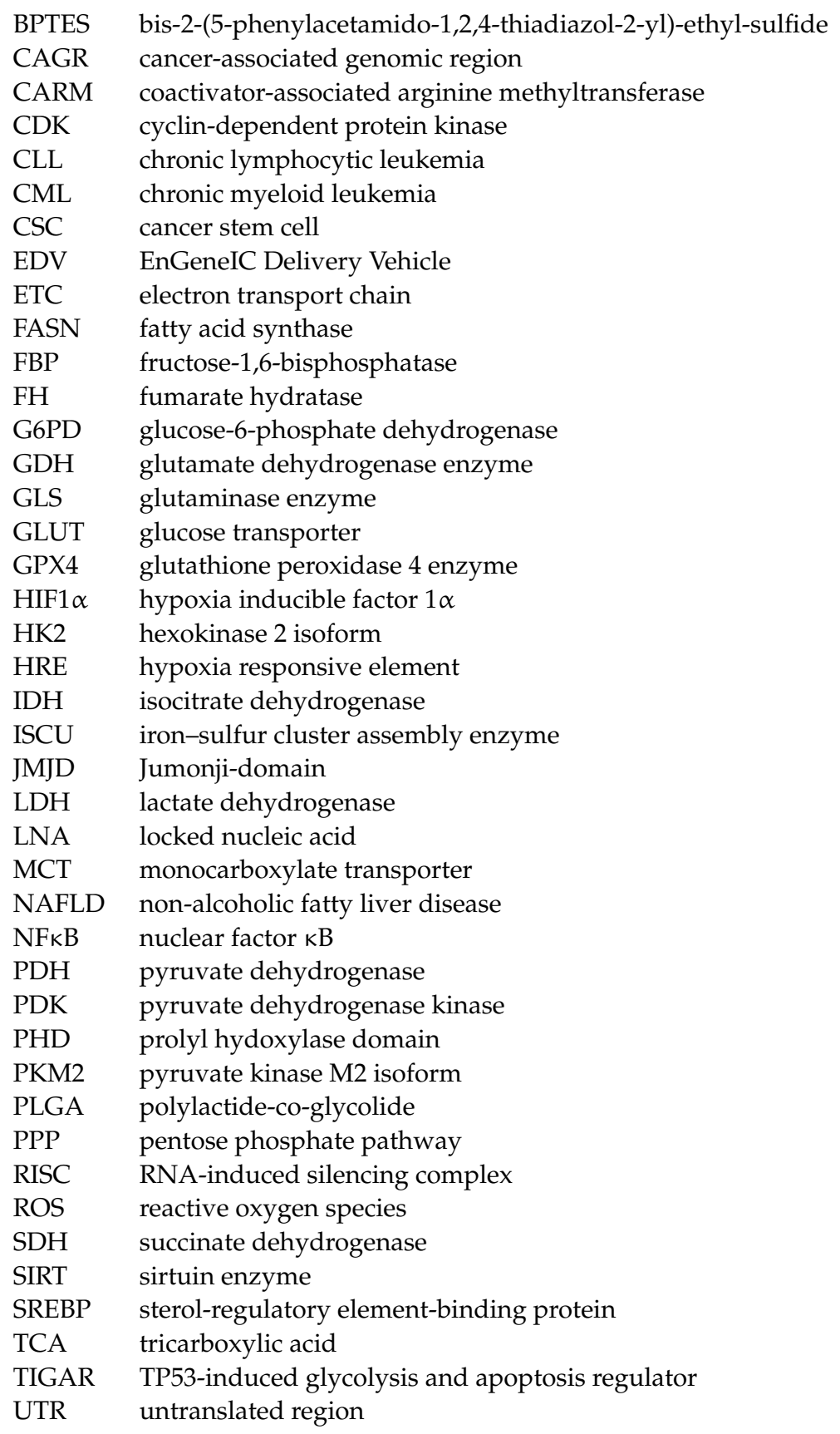

\section{References}

1. Hanahan, D.; Weinberg, R.A. The hallmarks of cancer. Cell 2000, 100, 57-70. [CrossRef]

2. Hanahan, D.; Weinberg, R.A. Hallmarks of cancer: The next generation. Cell 2011, 144, 646-674. [CrossRef]

3. Koppenol, W.H.; Bounds, P.L.; Dang, C.V. Otto Warburg's contributions to current concepts of cancer metabolism. Nat. Rev. Cancer 2011, 11, 325-337. [CrossRef]

4. Warburg, O. Versuche an überlebendem Carcinomgewebe. Biochem. Zschr. 1923, 142, 317-333. [CrossRef]

5. Potter, M.; Newport, E.; Morten, K.J. The Warburg effect: 80 years on. Biochem Soc. Trans. 2016, 44, 1499-1505. [CrossRef]

6. Heitz, E. Das Heterochromatin der Moose. Jahrb. Wiss. Bot. 1928, 69, 762-818.

7. Zhou, Z.; Yan, R.; Jiang, W.; Irudayaraj, J.M.K. Chromatin hierarchical branching visualized at the nanoscale by electron microscopy. Nanoscale Adv. 2020, 3, 1019-1028. [CrossRef] [PubMed]

8. Waddington, C.H. Canalization of development and genetic assimilation of acquired characters. Nature 1959, 183, 1654-1655. [CrossRef] [PubMed]

9. Nicoglou, A. Waddington's epigenetics or the pictorial meetings of development and genetics. Hist. Philos. Life Sci. 2018, 40, 61. [CrossRef] [PubMed] 
10. Feinberg, A.P.; Vogelstein, B. Hypomethylation distinguishes genes of some human cancers from their normal counterparts. Nature 1983, 301, 89-92. [CrossRef] [PubMed]

11. Feinberg, A. Interview: Professor Andrew Feinberg speaks to epigenomics. Epigenomics 2009, 1, 25-27. [CrossRef]

12. Jones, P.A.; Baylin, S.B. The fundamental role of epigenetic events in cancer. Nat. Rev. Genet. 2002, 3, 415-428. [CrossRef] [PubMed]

13. Wong, C.C.; Qian, Y.; Yu, J. Interplay between epigenetics and metabolism in oncogenesis: Mechanisms and therapeutic approaches. Oncogene 2017, 36, 3359-3374. [CrossRef] [PubMed]

14. Yu, Z.; Li, Z.; Jolicoeur, N.; Zhang, L.; Fortin, Y.; Wang, E.; Wu, M.; Shen, S.H. Aberrant allele frequencies of the SNPs located in microRNA target sites are potentially associated with human cancers. Nucleic Acids Res. 2007, 35, 4535-4541. [CrossRef]

15. Rupaimoole, R.; Slack, F.J. MicroRNA therapeutics: Towards a new era for the management of cancer and other diseases. Nat. Rev. Drug Discov. 2017, 16, 203-222. [CrossRef] [PubMed]

16. Bartel, D.P. MicroRNAs: Genomics, biogenesis, mechanism, and function. Cell 2004, 116, 281-297. [CrossRef]

17. Tafrihi, M.; Hasheminasab, E. MiRNAs: Biology, biogenesis, their web-based tools and databases. Microrna 2019, 8, 4-27. [CrossRef]

18. Kim, V.N. MicroRNA biogenesis: Coordinated cropping and dicing. Nat. Rev. Mol. Cell Biol. 2005, 6, 376-385. [CrossRef]

19. Nikitina, E.G.; Urazova, L.N.; Stegny, V.N. MicroRNAs and human cancer. Exp. Oncol. 2012, 34, 2-8.

20. Li, S.; Patel, D.J. Drosha and Dicer: Slicers cut from the same cloth. Cell Res. 2016, 26, 511-512. [CrossRef]

21. Lee, R.C.; Feinbaum, R.L.; Ambros, V. The C. elegans heterochronic gene lin-4 encodes small RNAs with antisense complementarity to lin-14. Cell 1993, 75, 843-854. [CrossRef]

22. Landgraf, P.; Rusu, M.; Sheridan, R.; Sewer, A.; Iovino, N.; Aravin, A.; Pfeffer, S.; Rice, A.; Kamphorst, A.O.; Landthaler, M.; et al. A Mammalian microRNA Expression Atlas Based on Small RNA Library Sequencing. Cell 2007, 129, 1401-1414. [CrossRef]

23. Lu, J.; Getz, G.; Miska, E.A.; Alvarez-Saavedra, E.; Lamb, J.; Peck, D.; Sweet-Cordero, A.; Ebert, B.L.; Mak, R.H.; Ferrando, A.A.; et al. MicroRNA expression profiles classify human cancers. Nature 2005, 435, 834-838. [CrossRef] [PubMed]

24. Leichter, A.L.; Sullivan, M.J.; Eccles, M.R.; Chatterjee, A. MicroRNA expression patterns and signalling pathways in the development and progression of childhood solid tumours. Mol. Cancer 2017, 16, 15. [CrossRef] [PubMed]

25. Calin, G.A.; Croce, C.M. MicroRNA-Cancer Connection: The Beginning of a New Tale. Cancer Res. 2006, 66, 7390-7394. [CrossRef] [PubMed]

26. Calin, G.A.; Dumitru, C.D.; Shimizu, M.; Bichi, R.; Zupo, S.; Noch, E.; Aldler, H.; Rattan, S.; Keating, M.; Rai, K.; et al. Frequent deletions and down-regulation of micro- RNA genes miR15 and miR16 at 13q14 in chronic lymphocytic leukemia. Proc. Natl. Acad. Sci. USA 2002, 99, 15524-15529. [CrossRef] [PubMed]

27. Kunej, T.; Godnic, I.; Horvat, S.; Zorc, M.; Calin, G.A. Cross Talk Between MicroRNA and Coding Cancer Genes. Cancer J. 2012, 18, 223-231. [CrossRef]

28. Zhang, B.; Pan, X.; Cobb, G.P.; Anderson, T.A. MicroRNAs as oncogenes and tumor suppressors. Dev. Biol. 2006, $302,1-12$. [CrossRef]

29. Satoh, J.; Tabunoki, H. Comprehensive analysis of human microRNA target networks. BioData Min. 2011, 4, 17. [CrossRef]

30. Planell-Saguer, M.; Rodicio, M.C. Analytical aspects of microRNA in diagnostics: A review. Anal. Chim. Acta 2011, 699, 134-152. [CrossRef]

31. Volinia, S.; Galasso, M.; Costinean, S.; Tagliavini, L.; Gamberoni, G.; Drusco, A.; Marchesini, J.; Mascellani, N.; Sana, M.E.; Jarour, R.A.; et al. Reprogramming of miRNA networks in cancer and leukemia. Genome Res. 2010, 20, 589-599. [CrossRef] [PubMed]

32. Mens, M.M.J.; Ghanbari, M. Cell cycle regulation of stem cells by microRNAs. Stem Cell Rev. Rep. 2018, 14, 309-322. [CrossRef]

33. Pickering, M.T.; Stadler, B.M.; Kowalik, T.F. miR-17 and miR-20a temper an E2F1-induced G1 checkpoint to regulate cell cycle progression. Oncogene 2009, 28, 140-145. [CrossRef] [PubMed]

34. Balzeau, J.; Menezes, M.R.; Cao, S.; Hagan, J.P. The lin28/let-7 pathway in cancer. Front. Genet. 2017, 8, 31. [CrossRef] [PubMed]

35. Shayimu, P.; Yusufu, A.; Rehemutula, A.; Redati, D.; Jiapaer, R.; Tuerdi, R. MicroRNA-377 Counteracts with Cancer Stem Cell Phenotypes and Epithelial Mesenchymal Transformation by Targeting ZEB2 in Colon Cancer. Technol. Cancer Res. Treat. 2020, 19, 1533033820967475. [CrossRef] [PubMed]

36. Ren, D.; Wang, M.; Guo, W.; Huang, S.; Wang, Z.; Zhao, X.; Du, H.; Song, L.; Peng, X. Double-negative feedback loop between ZEB2 and miR-145 regulates epithelial-mesenchymal transition and stem cell properties in prostate cancer cells. Cell Tissue Res. 2014, 358, 763-778. [CrossRef]

37. Peng, Y.; Croce, C.M. The role of microRNAs in human cancer. Signal. Transduct. Ther. 2016, 1, 15004. [CrossRef]

38. Yeung Wong, K.; Chiu So, C.; Loong, F.; Ping Chung, L.; Lung Lam, W.W.; Liang, R.; Kam Hop Li, G.; Jin, D.Y.; Chim, C.S. Epigenetic inactivation of the miR-124-1 in hematological malignancies. PLoS ONE 2011, 6, e19027. [CrossRef]

39. Chim, C.S.; Wong, K.Y.; Qi, Y.; Loong, F.; Lam, W.L.; Wong, L.G.; Jin, D.Y.; Costello, J.F.; Liang, R. Epigenetic inactivation of the miR-34a in hematological malignancies. Carcinogenesis 2010, 31, 745-750. [CrossRef]

40. Brait, M.; Sidransky, D. Cancer epigenetics: Above and beyond. Toxicol. Mech. Methods 2011, 21, 275-288. [CrossRef]

41. Rottiers, V.; Naar, A.M. MicroRNAs in metabolism and metabolic disorders. Nat. Rev. Mol. Cell Biol. 2012, 13, 239-250. [CrossRef] [PubMed]

42. Lewis, A.P.; Jopling, C.L. Regulation and biological function of the liver-specific miR-122. Biochem. Soc. Trans. 2010, 38, 1553-1557. [CrossRef] [PubMed] 
43. Gerin, I.; Clerbaux, L.A.; Haumont, O.; Lanthier, N.; Das, A.K.; Burant, C.F.; Leclercq, I.A.; MacDougald, O.A.; Bommer, G.T. Expression of miR-33 from an SREBP2 intron inhibits cholesterol export and fatty acid oxidation. J. Biol. Chem. 2010, 285, 33652-33661. [CrossRef]

44. Chen, B.; Liu, Y.; Jin, X.; Lu, W.; Liu, J.; Xia, Z.; Yuan, Q.; Zhao, X.; Xu, N.; Liang, S. MicroRNA-26a regulates glucose metabolism by direct targeting PDHX in colorectal cancer cells. BMC Cancer 2014, 14, 443. [CrossRef]

45. Zhu, Y.; Wu, G.; Yan, W.; Zhan, H.; Sun, P. MiR-146b-5p regulates cell growth, invasion, and metabolism by targeting PDHB in colorectal cancer. Am. J. Cancer Res. 2017, 7, 1136-1150.

46. Geiger, J.; Dalgaard, L.T. Interplay of mitochondrial metabolism and microRNAs. Cell Mol. Life Sci. 2017, 74, 631-646. [CrossRef]

47. Gong, H.; Zhang, M.; Han, Y.; Zhang, Y.; Pang, J.; Zhao, Y.; Chen, B.; Wu, W.; Qi, R.; Zhang, T. Differential microRNAs expression profiles in liver from three different lifestyle modification mice models. BMC Genom. 2021, 22, 196. [CrossRef]

48. Domanska-Senderowska, D.; Laguette, M.J.N.; Jegier, A.; Cieszczyk, P.; September, A.V.; Brzezianska-Lasota, E. MicroRNA profile and adaptive response to exercise training: A review. Int. J. Sports Med. 2019, 40, 227-235. [CrossRef]

49. Vasu, S.; Kumano, K.; Darden, C.M.; Rahman, I.; Lawrence, M.C.; Naziruddin, B. MicroRNA signatures as future biomarkers for diagnosis of diabetes states. Cells 2019, 8, 1533. [CrossRef]

50. Dongiovanni, P.; Meroni, M.; Longo, M.; Fargion, S.; Fracanzani, A.L. miRNA Signature in NAFLD: A turning point for non-invasive diagnosis. Int. J. Mol. Sci. 2018, 19, 3966. [CrossRef] [PubMed]

51. Warburg, O. Über den heutigen Stand des Carcinomproblems. Naturwiss 1927, 15, 1-4. [CrossRef]

52. Vaupel, P.; Schmidberger, H.; Mayer, A. The Warburg effect: Essential part of metabolic reprogramming and central contributor to cancer progression. Int. J. Radiat. Biol. 2019, 95, 912-919. [CrossRef]

53. Warburg, O. On the origin of cancer cells. Science 1956, 123, 309-314. [CrossRef] [PubMed]

54. Senyilmaz, D.; Teleman, A.A. Chicken or the egg: Warburg effect and mitochondrial dysfunction. F1000Prime Rep. 2015, 7, 41. [CrossRef]

55. Vaupel, P.; Multhoff, G. Revisiting the Warburg effect: Historical dogma versus current understanding. J. Physiol. 2021, 599, 1745-1757. [CrossRef] [PubMed]

56. Chen, B.; Li, H.; Zeng, X.; Yang, P.; Liu, X.; Zhao, X.; Liang, S. Roles of microRNA on cancer cell metabolism. J. Transl. Med. 2012, 10, 228. [CrossRef] [PubMed]

57. Van der Heiden, M.G.; Cantley, L.C.; Thompson, C.B. Understanding the Warburg effect: The metabolic requirements of cell proliferation. Science 2009, 324, 1029-1033. [CrossRef]

58. Dang, C.V. Rethinking the Warburg effect with Myc micromanaging glutamine metabolism. Cancer Res. 2010, 70, 859-862. [CrossRef]

59. Abdel-Magid, A.F. Glutaminase GLS1 inhibitors as potential cancer treatment. ACS Med. Chem. Lett. 2016, 7, 207-208. [CrossRef]

60. Hay, N. Reprogramming glucose metabolism in cancer: Can it be exploited for cancer therapy? Nat. Rev. Cancer 2016, 16, 635-649. [CrossRef]

61. Liberti, M.V.; Locassale, J.W. The Warburg effect: How does it benefit cancer cells? Trends Biochem. Sci. 2016, 41, 211-218. [CrossRef]

62. Yang, M.; Su, H.; Soga, T.; Kranc, K.R.; Pollard, P.J. Prolyl hydroxylase domain enzymes: Important regulators of cancer metabolism. Hypoxia 2014, 2, 127-142. [CrossRef]

63. Mushtaq, M.; Darekar, S.; Klein, G.; Kashuba, E. Different Mechanisms of Regulation of the Warburg Effect in Lymphoblastoid and Burkitt Lymphoma Cells. PLoS ONE 2015, 10, e0136142. [CrossRef] [PubMed]

64. Bernasconi, P.; Borsani, O. Targeting leukemia stem cell-niche dynamics: A new challenge in AML treatment. J. Oncol. 2019, 2019, 8323592. [CrossRef] [PubMed]

65. Akins, N.S.; Nielson, T.C.; Le, H.V. Inhibition of Glycolysis and Glutaminolysis: An Emerging Drug Discovery Approach to Combat Cancer. Curr. Top. Med. Chem. 2018, 18, 494-504. [CrossRef]

66. Ghoneum, A.; Abdulfattah, A.Y.; Warren, B.O.; Shu, J.; Said, N. Redox Homeostasis and Metabolism in Cancer: A Complex Mechanism and Potential Targeted Therapeutics. Int. J. Mol. Sci. 2020, 21, 3100. [CrossRef]

67. Bensaad, K.; Tsuruta, A.; Selak, M.A.; Calvo Vidal, M.N.; Nakano, K.; Bartrons, R.; Gottlieb, E.; Vousden, K.H. TIGAR, a p53-inducible regulator of glycolysis and apoptosis. Cell 2006, 126, 107-120. [CrossRef] [PubMed]

68. Carvalho, K.C.; Cunha, I.W.; Rocha, R.M.; Ayala, F.R.; Cajaíba, M.M.; Begnami, M.D.; Vilela, R.S.; Paiva, G.R.; Andrade, R.G.; Soares, F.A. GLUT1 expression in malignant tumors and its use as an immunodiagnostic marker. Clinics 2011, 66, 965-972. [CrossRef]

69. Ullah, M.S.; Davies, A.J.; Halestrap, A.P. The plasma membrane lactate transporter MCT4, but not MCT1, is up-regulated by hypoxia through a HIF-1alpha-dependent mechanism. J. Biol. Chem. 2006, 281, 9030-9037. [CrossRef] [PubMed]

70. Yang, L.; Venneti, S.; Nagrath, D. Glutaminolysis: A hallmark of cancer metabolism. Ann. Rev. Biomed. Engin. 2017, 19, 163-194. [CrossRef]

71. Choi, J.; Kim, E.S.; Koo, J.S. Expression of pentose phosphate pathway-related proteins in breast cancer. Dis. Markers 2018, 2018, 9369358. [CrossRef] [PubMed]

72. Perillo, B.; Di Donato, M.; Pezone, A.; Di Zazzo, E.; Giovannelli, P.; Galasso, G.; Castoria, G.; Migliaccio, A. ROS in cancer therapy: The bright side of the moon. Exp. Mol. Med. 2020, 52, 192-203. [CrossRef] [PubMed]

73. Sullivan, L.B.; Chandel, N.S. Mitochondrial reactive oxygen species and cancer. Cancer Metab. 2014, 2, 17. [CrossRef] [PubMed] 
74. Wang, T.X.; Liang, J.Y.; Zhang, C.; Xiong, Y.; Guan, K.L.; Yuan, H.X. The oncometabolite 2-hydroxyglutarate produced by mutant IDH1 ssensitizes cells to ferroptosis. Cell Death Dis. 2019, 10, 755. [CrossRef] [PubMed]

75. Xu, W.; Yang, H.; Liu, Y.; Yang, Y.; Wang, P.; Kim, S.H.; Ito, S.; Yang, C.; Wang, P.; Xiao, M.T.; et al. Oncometabolite 2hydroxyglutarate is a competitive inhibitor of $\alpha$-ketoglutarate-dependent dioxygenases. Cancer Cell. 2011, 19, 17-30. [CrossRef]

76. Fong, G.H.; Takeda, K. Role and regulation of prolyl hydroxylase domain proteins. Cell Death Differ. 2008, 15, 635-641. [CrossRef]

77. Galluzzi, L.; Kroemer, G. Potent immunosuppressive effects of the oncometabolite R-2-hydroxyglutarate. Oncoimmunology 2018, 7, e1528815. [CrossRef]

78. Wang, J.H.; Chen, W.L.; Li, J.M.; Wu, S.F.; Chen, T.L.; Zhu, Y.M.; Zhang, W.N.; Li, Y.; Qiu, Y.P.; Zhao, A.H.; et al. Prognostic significance of 2-hydroxyglutarate levels in acute myeloid leukemia in China. Proc. Natl. Acad. Sci. USA 2013, 110, 17017-17022. [CrossRef]

79. Marquez, J.; Flores, J.; Kim, A.H.; Nyamaa, B.; Tuyet-Nguyen, A.T.; Park, N.; Han, J. Rescue of TCA cycle dysfunction for cancer therapy. J. Clin. Med. 2019, 8, 2161. [CrossRef]

80. Kim, J.; DeBerardinis, R.J. Mechanisms and implications of metabolic heterogeneity in cancer. Cell Metab. 2019, 30, 434-446. [CrossRef] [PubMed]

81. Wilde, L.; Roche, M.; Domingo-Vidal, M.; Tanson, K.; Philp, N.; Curry, J.; Martinez-Outschoorn, U. Metabolic coupling and the Reverse Warburg Effect in cancer: Implications for novel biomarker and anticancer agent development. Semin. Oncol. 2017, 44, 198-203. [CrossRef]

82. Subramaniam, S.; Jeet, V.; Clements, J.A.; Gunter, J.H.; Batra, J. Emergence of microRNAs as key players in cancer cell metabolism. J. Clin. Chem. 2019, 65, 1090-1101. [CrossRef]

83. Izreig, S.; Samborska, B.; Johnson, R.M.; Sergushichev, A.; Ma, E.H.; Lussier, C.; Loginicheva, E.; Donayo, A.O.; Poffenberger, M.C.; Sagan, S.M.; et al. The miR-17 92 microRNA Cluster Is a Global Regulator of Tumor Metabolism. Cell Rep. 2016, 16, 1915-1928. [CrossRef]

84. Favaro, E.; Ramachandran, A.; McCormick, R.; Gee, H.; Blancher, C.; Crosby, M.; Devlin, C.; Blick, C.; Buffa, F.; Li, J.L.; et al. MicroRNA-210 regulates mitochondrial free radical response to hypoxia and Krebs cycle in cancer cells by targeting iron sulfur cluster protein ISCU. PLoS ONE 2010, 5, e10345. [CrossRef]

85. Qu, W.; Ding, S.M.; Cao, G.; Wang, S.J.; Zheng, X.H.; Li, G.H. MiR132 mediates a metabolic shift in prostate cancer cells by targeting Glut1. FEBS Open Bio 2016, 6, 735-741. [CrossRef]

86. Li, P.; Yang, X.; Cheng, Y.; Zhang, X.; Yang, C.; Deng, X.; Li, P.; Tao, J.; Yang, H.; Wei, J.; et al. MicroRNA-218 increases the sensitivity of bladder cancer to cisplatin by targeting Glut1. Cell Physiol. Biochem. 2017, 41, 921-932. [CrossRef]

87. Zhang, L.F.; Jiang, S.; Liu, M.F. MicroRNA regulation and analytical methods in cancer cell metabolism. Cell Mol. Life Sci. 2017, 74, 2929-2941. [CrossRef] [PubMed]

88. Fong, M.Y.; Zhou, W.; Liu, L.; Alontaga, A.Y.; Chandra, M.; Ashby, J.; Chow, A.; O'Connor, S.T.F.; Li, S.; Chin, A.R.; et al. Breast-cancer-secreted miR-122 reprograms glucose metabolism in premetastatic niche to promote metastasis. Nat. Cell Biol. 2015, 17, 183-194. [CrossRef]

89. Wu, H.; Wang, Y.; Wu, C.; Yang, P.; Li, H.; Li, Z. Resveratrol induces cancer cell apoptosis through miR-326/PKM2- mediated ER stress and mitochondrial fission. J. Agric. Food Chem. 2016, 64, 9356-9367. [CrossRef]

90. Brown, N.J.; Higham, S.E.; Perunovic, B.; Arafa, M.; Balasubramanian, S.; Rehman, I. Lactate dehydrogenase-B is silenced by promoter methylation in a high frequency of human breast cancers. PLoS ONE 2013, 8, e57697. [CrossRef]

91. Wang, J.; Wang, H.; Liu, A.; Fang, C.; Hao, J.; Wang, Z. Lactate dehydrogenase A negatively regulated by miRNAs promotes aerobic glycolysis and is increased in colorectal cancer. Oncotarget 2015, 6, 19456-19468. [CrossRef] [PubMed]

92. He, Z.; Li, Z.; Zhang, X.; Yin, K.; Wang, W.; Xu, Z.; Li, B.; Zhang, L.; Xu, J.; Sun, G.; et al. MiR-422a regulates cellular metabolism and malignancy by targeting pyruvate dehydrogenase kinase 2 in gastric cancer. Cell Death Dis. 2018, 9, 505. [CrossRef] [PubMed]

93. Dong, J.; Xiao, D.; Zhao, Z.; Ren, P.; Li, C.; Hu, Y.; Shi, J.; Su, H.; Wang, L.; Liu, H.; et al. Epigenetic silencing of microRNA-13 7 enhances ASCT2 expression and tumor glutamine metabolism. Oncogenesis 2017, 6, e356. [CrossRef]

94. Wang, N.; Tan, H.Y.; Feng, Y.G.; Zhang, C.; Chen, F.; Feng, Y. microRNA-23a in human cancer: Its roles, mechanisms and therapeutic relevance. Cancers 2018, 11, 7. [CrossRef]

95. Xin, M.; Qiao, Z.; Li, J.; Liu, J.; Song, S.; Zhao, X.; Miao, P.; Tang, T.; Wang, L.; Liu, W.; et al. MiR-22 inhibits tumor growth and metastasis by targeting ATP citrate lyase: Evidence in osteosarcoma, prostate cancer, cervical cancer and lung cancer. Oncotarget 2016, 7, 44252-44265. [CrossRef]

96. Wang, J.; Zhang, X.; Shi, J.; Cao, P.; Wan, M.; Zhang, Q.; Wang, Y.; Kridel, S.J.; Liu, W.; Xu, J.; et al. Fatty acid synthase is a primary target of MiR-15a and MiR-16-1 in breast cancer. Oncotarget 2016, 7, 78566-78576. [CrossRef]

97. Yang, H.; Wu, X.L.; Wu, K.H.; Zhang, R.; Ju, L.L.; Ji, Y.; Zhang, Y.W.; Xue, S.L.; Zhang, Y.X.; Yang, Y.F.; et al. MicroRNA-497 regulates cisplatin chemosensitivity of cervical cancer by targeting transketolase. Am. J. Cancer Res. 2016, 6, $2690-2699$.

98. Li, M.; Zhang, X.; Lu, Y.; Meng, S.; Quan, H.; Hou, P.; Tong, P.; Chai, D.; Gao, X.; Zheng, J.; et al. The nuclear translocation of transketolase inhibits the farnesoid receptor expression by promoting the binding of HDAC3 to FXR promoter in hepatocellular carcinoma cell lines. Cell Death Dis. 2020, 11, 31. [CrossRef] [PubMed]

99. Liu, X.; Wang, X.; Zhang, J.; Lam, E.K.Y.; Shin, V.Y.; Cheng, A.S.L.; Yu, J.; Chan, F.K.L.; Sung, J.J.Y.; Jin, H.C. Warburg effect revisited: An epigenetic link between glycolysis and gastric carcinogenesis. Oncogene 2010, 29, 442-450. [CrossRef] [PubMed] 
100. Yen, C.Y.; Huang, H.W.; Shu, C.W.; Hou, M.F.; Yuan, S.S.; Wang, H.R.; Chang, Y.T.; Farooqi, A.A.; Tang, J.Y.; Chang, H.W. DNA methylation, histone acetylation and methylation of epigenetic modifications as a therapeutic approach for cancers. Cancer Lett. 2016, 373, 185-192. [CrossRef]

101. Kottakis, F.; Nicolay, B.N.; Roumane, A.; Karnik, R.; Gu, H.; Nagle, J.M.; Boukhali, M.; Hayward, M.C.; Li, Y.Y.; Chen, T.; et al. LKB1 loss links serine metabolism to DNA methylation and tumorigenesis. Nature 2016, 539, 390-395. [CrossRef] [PubMed]

102. Lopez-Serra, P.; Marcilla, M.; Villanueva, A.; Ramos-Fernandez, A.; Palau, A.; Leal, L.; Wahi, J.E.; Setien-Baranda, F.; Szczesna, K.; Moutinho, C.; et al. A DERL3-associated defect in the degradation of SLC2A1 mediates the Warburg effect. Nat. Commun. 2014, 5, 3608. [CrossRef]

103. Jing, Y.Y.; Cai, F.F.; Zhang, L.; Han, J.; Yang, L.; Tang, F.; Li, Y.B.; Chang, J.F.; Sung, F.; Yang, X.M.; et al. Epigenetic regulation of the Warburg effect by H2B monoubiquitination. Cell Death Differ. 2020, 27, 1660-1676. [CrossRef]

104. Miranda-Goncalves, V.; Lameirinhas, A.; Henrique, R.; Jeronimo, C. Metabolism and Epigenetic Interplay in Cancer: Regulation and Putative Therapeutic Targets. Front. Genet. 2018, 9, 427. [CrossRef]

105. Guarente, L. Calorie restriction and sirtuins revisited. Genes Dev. 2013, 27, 2072-2085. [CrossRef]

106. Bell, E.L.; Emerling, B.M.; Ricoult, S.J.H.; Guarente, L. SirT3 suppresses hypoxia inducible factor $1 \alpha$ and tumor growth by inhibiting mitochondrial ROS production. Oncogene 2011, 30, 2986-2996. [CrossRef] [PubMed]

107. Haigis, M.C.; Mostoslavsky, R.; Haigis, K.M.; Fahie, K.; Christodoulou, D.C.; Murphy, A.J.; Valenzuela, D.M.; Yancopoulos, G.D.; Karow, M.; Blander, G.; et al. SIRT4 inhibits glutamate dehydrogenase and opposes the effects of calorie restriction in pancreatic beta cells. Cell 2006, 126, 941-954. [CrossRef] [PubMed]

108. Min, Z.; Gao, J.; Yu, Y. The roles of mitochondrial SIRT4 in cellular metabolism. Front. Endocrinol. 2019, 9, 783. [CrossRef] [PubMed]

109. Jeong, S.M.; Xiao, C.; Finley, L.W.S.; Lahusen, T.; Souza, A.L.; Pierce, K.; Li, Y.H.; Wang, X.; Laurent, G.; German, N.J.; et al. SIRT4 has tumor-suppressive activity and regulates the cellular metabolic response to DNA damage by inhibiting mitochondrial glutamine metabolism. Cancer Cell. 2013, 23, 450-463. [CrossRef] [PubMed]

110. Al-Azzam, N. Sirtuin 6 and metabolic genes interplay in Warburg effect in cancers. J. Clin. Biochem. Nutr. 2020, 66, 169-175. [CrossRef] [PubMed]

111. Islamian, J.P.; Aghaee, F.; Farajollahi, A.; Baradaran, B.; Fazel, M. Combined Treatment with 2-Deoxy-D-Glucose and Doxorubicin Enhances the in Vitro Efficiency of Breast Cancer Radiotherapy. Asian Pac. J. Cancer Prev. 2015, 16, 8431-8438. [CrossRef]

112. Liu, Y.; Cao, Y.; Zhang, W.; Bergmeier, S.; Qian, Y.; Akbar, H.; Colvin, R.; Ding, J.; Tong, L.; Wu, S.; et al. A small-molecule inhibitor of glucose transporter 1 downregulates glycolysis, induces cell-cycle arrest, and inhibits cancer cell growth in vitro and in vivo. Mol. Cancer Ther. 2012, 11, 1672-1682. [CrossRef]

113. Wu, Q.; Ba-Alawi, W.; Deblois, G.; Cruickshank, J.; Duan, S.; Lima-Fernandes, E.; Haight, J.; Tonekaboni, S.A.M.; Fortier, A.M.; Kuasne, H.; et al. GLUT1 inhibition blocks growth of RB1-positive triple negative breast cancer. Nat. Commun. 2020, $11,4205$. [CrossRef]

114. Le Calvé, B.; Rynkowski, M.; Le Mercier, M.; Bruyère, C.; Lonez, C.; Gras, T.; Haibe-Kains, B.; Bontempi, G.; Decaestecker, C.; Ruysschaert, J.M.; et al. Long-term in vitro treatment of human glioblastoma cells with temozolomide increases resistance in vivo through up-regulation of GLUT transporter and aldo-keto reductase enzyme AKR1C expression. Neoplasia 2010, 12, 727-739. [CrossRef]

115. Hulleman, E.; Kazemier, K.M.; Holleman, A.; VanderWeele, D.J.; Rudin, C.M.; Broekhuis, M.J.; Evans, W.E.; Pieters, R.; Den Boer, M.L. Inhibition of glycolysis modulates prednisolone resistance in acute lymphoblastic leukemia cells. Blood 2009, 113, $2014-2021$. [CrossRef]

116. Shi, H.S.; Li, D.; Zhang, J.; Wang, Y.S.; Yang, L.; Zhang, H.L.; Wang, X.H.; Mu, B.; Wang, W.; Ma, Y.; et al. Silencing of pkm2 increases the efficacy of docetaxel in human lung cancer xenografts in mice. Cancer Sci. 2010, 101, 1447-1453. [CrossRef]

117. Popovici-Muller, J.; Saunders, J.O.; Salituro, F.G.; Travins, J.M.; Yan, S.; Zhao, F.; Gross, S.; Dang, L.; Yen, K.E.; Yang, H.; et al. Discovery of the first potent inhibitors of mutant IDH1 that lower tumor 2-HG in vivo. ACS Med. Chem. Lett. 2012, 3, 850-855. [CrossRef]

118. Rohle, D.; Popovici-Muller, J.; Palaskas, N.; Turcan, S.; Grommes, C.; Campos, C.; Tsoi, J.; Clark, O.; Oldrini, B.; Komisopoulou, E.; et al. An inhibitor of mutant IDH1 delays growth and promotes differentiation of glioma cells. Science 2013, 340, 626-630. [CrossRef]

119. Choi, Y.K.; Park, K.G. Targeting Glutamine Metabolism for Cancer Treatment. Biomol. Ther. 2018, 26, 19-28. [CrossRef] [PubMed]

120. DeBerardinis, R.J.; Chandel, N.S. Fundamentals of Cancer Metabolism. Sci Adv. 2016, 2, e1600200. [CrossRef] [PubMed]

121. Stockard, B.; Bhise, N.; Shin, M.; Guingab-Cagmat, J.; Garrett, T.J.; Pounds, S.; Lamba, J.K. Cellular metabolomics profiles associated with drug chemosensitivity in AML. Front. Oncol. 2021, 11, 678008. [CrossRef] [PubMed]

122. Pike, L.S.; Smift, A.L.; Croteau, N.J.; Ferrick, D.A.; Wu, M. Inhibition of fatty acid oxidation by etomoxir impairs NADPH production and increases reactive oxygen species resulting in ATP depletion and cell death in human glioblastoma cells. Biochim. Biophys. Acta 2011, 1807, 726-734. [CrossRef]

123. Suganuma, K.; Miwa, H.; Imai, N.; Shikami, M.; Gotou, M.; Goto, M.; Mizuno, S.; Takahashi, M.; Yamamoto, H.; Hiramatsu, A.; et al. Energy metabolism of leukemia cells: Glycolysis versus oxidative phosphorylation. Leuk. Lymphoma 2010, 51, 2112-2119. [CrossRef]

124. Shah, V.; Shah, J. Recent trends in targeting miRNAs for cancer therapy. J. Pharm. Pharmacol. 2020, 72, 1732-1749. [CrossRef] 
125. Ye, J.; Zou, M.; Li, P.; Liu, H. MicroRNA Regulation of Energy Metabolism to Induce Chemoresistance in Cancers. Technol. Cancer Res. Treat. 2018, 17, 1533033818805997. [CrossRef]

126. Liu, L.; Chen, R.; Huang, S.; Wu, Y.; Li, G.; Zhang, B.; Liu, Q.; Yin, D.; Liang, Y. MiR-153 sensitized the K562 cells to As2O3-induced apoptosis. Med. Oncol. 2012, 29, 243-247. [CrossRef]

127. Zhang, L.; Chen, T.; Yin, Y.; Zhang, C.Y.; Zhang, Y.L. Dietary microRNA-A novel functional component of food. Adv. Nutr. 2019, 10, 711-721. [CrossRef]

128. Mi, S.; Lu, J.; Sun, M.; Li, Z.; Zhang, H.; Neilly, M.B.; Wang, Y.; Qian, Z.; Jin, J.; Zhang, Y.; et al. MicroRNA expression signatures accurately discriminate acute lymphoblastic leukemia from acute myeloid leukemia. Proc. Natl. Acad. Sci. USA 2007, 104, 19971-19976. [CrossRef] [PubMed]

129. Usuba, W.; Urabe, F.; Yamamoto, Y.; Matsuzaki, J.; Sasaki, H.; Ichikawa, M.; Takizawa, S.; Aoki, Y.; Niida, S.; Kato, K.; et al. Circulating miRNA panels for specific and early detection in bladder cancer. Cancer Sci. 2019, 110, 408-419. [CrossRef] [PubMed]

130. Singh, A.; Kant, R.; Saluja, T.S.; Tripathi, T.; Srivastava, K.; Naithani, M.; Gupta, A.; Mirza, A.A.; Prakash, V.; Singh, S.K. Differential diagnosis of non-small cell lung carcinoma by circulating microRNA. J. Cancer Res. Ther. 2020, 16, 127-131. [CrossRef] [PubMed]

131. Jinlong, S.; Lin, F.; Yonghui, L.; Li, Y.; Weidong, W. Identification of let-7a-2-3p or/and miR-188-5p as prognostic biomarkers in cytogenetically normal acute myeloid leukemia. PLoS ONE 2015, 10, e0118099. [CrossRef]

132. Lai, J.; Wang, H.; Pan, Z.; Su, F. A novel six-microRNA-based model to improve prognosis prediction of breast cancer. Aging 2019, 11, 649-662. [CrossRef] [PubMed]

133. Lv, Y.; Duanmu, J.; Fu, X.; Li, T.; Jiang, Q. Identifying a new microRNA signature as a prognostic biomarker in colon cancer. PLoS ONE 2020, 15, e0228575. [CrossRef] [PubMed]

134. Pedroza-Torres, A.; Romero-Cordoba, S.L.; Justo-Garrido, M.; Salido-Guadarrama, I.; Rodriguez-Bautista, R.; Montano, S.; Muniz-Mendoza, R.; Arriaga-Canon, C.; Fragoso-Ontiveros, V.; Alvarez-Gomez, R.M.; et al. MicroRNAs in tumor cell metabolism: Roles and therapeutic opportunities. Front. Oncol. 2019, 9, 1404. [CrossRef]

135. Han, J.; Chen, Q. MiR-16 modulate temozolomide resistance by regulating BCL-2 in human glioma cells. Int. J. Clin. Exp. Pathol. 2015, 8, 12698-12707. [PubMed]

136. Zhang, J.; Li, S.; Li, L.; Li, M.; Guo, C.; Yao, J.; Mi, S. Exosome and exosomal microRNA: Trafficking, sorting, and function. Genom. Proteom. Bioinform. 2015, 13, 17-24. [CrossRef]

137. Fabbri, M.; Paone, A.; Calore, F.; Galli, R.; Gaudio, E.; Santhanam, R. MicroRNAs bind to toll-like receptors to induce prometastatic inflammatory response. Proc. Natl. Acad. Sci. USA 2012, 109, E2110-E2116. [CrossRef]

138. Wang, X.; Zhang, H.; Yang, H.; Bai, M.; Ning, T.; Deng, T.; Liu, R.; Fan, Q.; Zhu, K.; Li, J.; et al. Exosome-delivered circRNA promotes glycolysis to induce chemoresistance through the miR-122-PKM2 axis in colorectal cancer. Mol. Oncol. 2020, 14, 539-555. [CrossRef] [PubMed]

139. Riley, P.A. Epimutation and cancer: Carcinogenesis viewed as error-prone inheritance of epigenetic information. J. Oncol. 2018, 2018, 2645095. [CrossRef] [PubMed]

140. Lytle, N.K.; Barber, A.G.; Reya, T. Stem cell fate in cancer growth, progression and therapy resistance. Nat. Rev. Cancer 2018, 18, 669-680. [CrossRef] [PubMed]

141. Zhu, X.; Chen, H.H.; Gao, C.Y.; Zhang, X.X.; Jiang, J.X.; Zhang, Y.; Fang, J.; Zhao, F.; Chen, Z.G. Energy metabolism in cancer stem cells. World J. Stem Cells 2020, 12, 448-461. [CrossRef] [PubMed]

142. Beg, M.S.; Brenner, A.J.; Sachdev, J.; Borad, M.; Kang, Y.K.; Stoudemire, J.; Smith, S.; Bader, A.G.; Kim, S.; Hong, D.S. Phase I study of MRX34, a liposomal miR-34a mimic, administered twice weekly in patients with advanced solid tumors. Investig. New Drugs 2017, 35, 180-188. [CrossRef] [PubMed] 